\title{
RELIGIOUS MESSAGES WITHOUT RELIGION IN NAS DAILY ONLINE VIDEOS (DISPLACEMENT ANALYSIS IN AUTHORITY)
}

\author{
Ahmad Assegaf ${ }^{*}$ \\ ${ }^{1}$ UIN Sunan Kalijaga Yogyakarta, Indonesia, e-mail: abmadassegaf95@gmail.com \\ *Corresponding Author

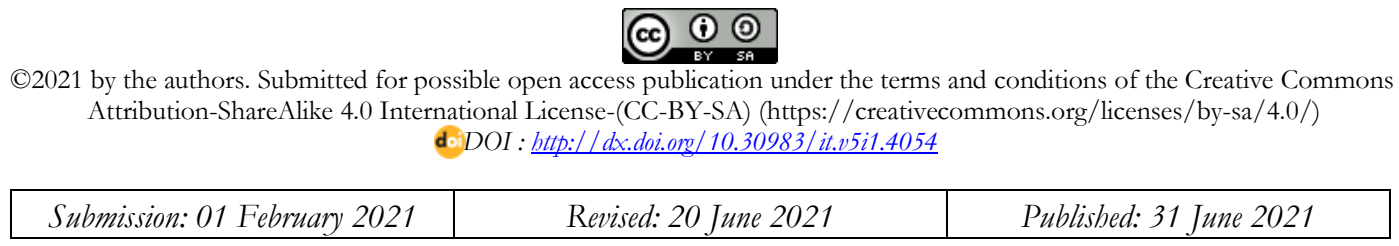

\begin{abstract}
The article tells about religious authority being taken over by content creators. The defeat of religious authorities arises because there are more and more people watching vlog videos than followers of religious authorities themselves. The link between video vlogs and religious authorities is video vlogs that accidentally take over the place or field of spreading religious knowledge. Observations were made through Facebook Nas Daily. This study uses Pauline Hope Cheong's Authority theory. In analyzing it, it is exactly the same as where Pauline hope Cheong explains his theory, namely through the four logics he considers to formulate the theory, namely disjucture and displacement as the formulation of the problem, and continuity and complementarity as solutions to problems. This research proves that religion is now not only obtained from religious authorities.
\end{abstract}

Keywords: Authority, Nas Daily, Religious authority, Displacement

\begin{abstract}
Abstrak
Artikel bercerita tentang otoritas keagamaan yang diambil alih oleh konten creator. kekalahan otoritas keagamaan muncul karena pengamat vidio vlog lebih banyak dan memiliki banyak kalangan daripada para pengikut dari otoritas keagmaan itu sendiri. Yang menghubungkan antara vlog video dengan otoritas keagamaan adalah video vlog yang tidak sengaja mengambil alih tempat atau lapangan penyebaran ilmu agama secara tidak sengaja. Pengamatan dilakukan melalui facebook Nas Daily. Penelitian ini menggunakan teori Authority milik Pauline Hope Cheong. Dalam mengalisisny a sama persis sebagai mana Pauline hope Cheong menenrangkan teorinya yaitu melalui empat logika yang dipertimbangkanya untuk. merumuskan teori yaitu disjucture dan displacement sebagai perumusan problematika, dan continuity dan Complementarity sebagai solusi probelematika. Penelitian ini membuktikan bahwa agama sekarang tidak hanya di dapat dari otoritas keagamaan.
\end{abstract}

Kata Kunci: Authority, Nas Daily, Otoritas keagamaan, Displacement

\section{Background}

Online videos are the main reference for religious listeners, beyond reading articles ${ }^{1}$. However, not all religious videos are reference material for religious knowledge. Some people follow lecture videos, and most of them

1 Eni Fariyatul Fahyuni and Wilna Aini, "Pengembangan Video Pembelajaran Tutorial Sujud Pada Mata Pelajaran Pendidikan Agama Islam Pada Sekolah Menengah Pertama," Halaqa: Islamic Education Journal 3, no. 1 (2019): 43-52, https://doi.org/10.21070/halaqa.v3i1.2116. follow videos with more active religious content ${ }^{2}$.

Nas Daily is an Israeli palestinian vlogger who has a one minute video channel on facebook and youtube, Nas Daily's video content is Human Interest (human

2 Oliver Roy, The Failure of Political Islam (Cambridge: Harvard University Press, 2003).

3 Dwi Haryanto, "Komodifikasi Agama Pada Media Sinema Sebagai Strategi Jualan Industri Perfilman Indonesia," Journal of Urban Society's Arts 4, no. 2 (2018): 61-70, https://doi.org/10.24821/jousa.v4i2.2161. 
activity) ${ }^{4}$. He travels around the world to create one-minute videos telling the hidden unique things that people around the world do that are useful for all of life ${ }^{5}$. One of the big Nas Daily videos is a video related to religious issues.

The interesting thing that concerns the author in this article is that Nas Daily's religious message which is not from a religious authority is more approved by more people including those who are not of the same religion as Nas-more than religious authorities ${ }^{6}$. Nas Daily presents a message of peace to all people in the world from all religions not to believe that their religion is the truest religion. This becomes large because the number of non-religious is more than religious ${ }^{7}$. This view becomes interesting because recently, when we look at the condition of new religious authorities, they are always proud of their religion. This is natural, but sometimes it goes beyond the limits to invite its adherents to hate other religions, which means giving the mindset that they -who are

${ }^{4}$ Joan-isaac Biel, Oya Aran, and Daniel GaticaPerez, "You Are Known by How You Vlog: Personality Impressions and Nonverbal Behavior in YouTube," Artificial Intelligence, 2011, 446-49.

5 Wen Gao et al., "Vlogging: A Survey of Videoblogging Technology on the Web," ACM Computing Surveys 42, no. 4 (2010), https://doi.org/10.1145/1749603.1749606; Joan Isaac Biel and Daniel Gatica-Perez, "Voices of Vlogging," ICWSM 2010 - Proceedings of the 4th International AAAI Conference on Weblogs and Social Media, 2010, 211-14.

6 Wahyudi Akmaliah, "Bukan Sekedar Penggaung (Buzzers): Media Sosial Dan Transformasi Arena Politik," Maarif 13, no. 1 (2018): 9-25, https://doi.org/10.47651/mrf.v13i1.9; Citra Nurjanah, Jujun Junaedi, and Uwes Fatoni, "Pesan Dakwah Minoritas Dalam Vlog," Tabligh: Jurnal Komunikasi Dan Penyiaran Islam 5, no. 4 (2020): 425-42, https://doi.org/10.15575/tabligh.v5i4.1485; Ting Hao Huang et al., "Visual Storytelling," 2016 Conference of the North American Chapter of the Association for Computational Linguistics: Human Language Technologies, NAACL HLT 2016 - Proceedings of the Conference, no. Dii (2016): 123339, https://doi.org/10.18653/v1/n16-1147.

${ }^{7}$ Roro Sri Rejeki Waluyajati and Herlina Nurani, "Islam Dan Studi Agama-Agama di Indonesia," Religious: Jurnal Agama Dan Lintas Budaya 1, no. 1 (2016): 51-62. of other religions- are enemies that must be avoided in every detail, even to the point of pronouncing sentences of appreciation to them as well. avoided as much as possible. And this also shows the teachings that prohibit people from interacting with people of other religions.

In this research, author uses the Authority theory because there is a displacement between vlogs (Nas Daily) and videos of religious authorities conveying religious knowledge ${ }^{8}$. In this study, the authors make a comparison between followers of religious authorities and followers of the Nas Daily vlogger. There is a thought that people who have not approached a certain religion must repent by approaching a religious authority ${ }^{9}$ Nas Dailyunintentionally-Makes things easier by respecting each other enough, and this gives rise to new beliefs that make people feel less guilty when they are not a religious authority or part of it ${ }^{10}$.

In the Authority theory developed by Pauline Hope Cheong, there are several logics used as concepts that form the indication of authority, including the logic of Disjuncture, Displacement, Continuity, and Complementarity ${ }^{11}$. The logic above explains how the Internet has taken over the traditional

8 Mohammad Zaki Arrobi and Amsa Nadzifah, "Otoritas Agama Di Era Korona: Dari Fragmentasi Ke Konvergensi?," Maarif 15, no. 1 (2020): 197-215, https://doi.org/10.47651/mrf.v15i1.85.

9 Fasha Umh Rizky and Nur Syam, "Mengubah Sikap Moderasi Beragama di Universitas Islam Negeri Sunan Ampel Surabaya," Jurnal Ilmu Komunikasi 11, no. 1 (2021); Unang Wahidin, "Implementasi Literasi Media Dalam Proses Pembelajaran Pendidikan Agama Islam Dan Budi Pekerti," Edukasi Islami: Jurnal Pendidikan Islam 7, no. $02 \quad$ (2018): 229 , https://doi.org/10.30868/ei.v7i2.284.

10 Mujahidil Mustaqim, "Analisis Nilai-Nilai Toleransi Dalam Kurikulum Pendidikan Agama," Jurnal Pendidikan Agama Islam 16, no. 1 (2019): 75-94, https://doi.org/10.14421/jpai.2019.161-05.

11 Heidi A. Campbell, Digital Religion: Understanding Religious Practice in New Media Worlds, Digital Religion: Understanding Religious Practice in New Media Worlds, 2012, https://doi.org/10.4324/9780203084861. 
version of religious authority which is usually the main reference in religious understanding ${ }^{12}$. Disjuncture is a logic of omission arising from the internet that removes religious authority. This is then reinforced by the logic of displacement, namely the logic of replacement that appears to occupy the place of traditional authority that has been removed 13 .

The two logics do not just stop, and take over religious authority ${ }^{14}$. However, it provides a solution by formulating the next two logics, namely Continuity Logic and Complementarity. Continuity logic is a logic that does not disturb traditional religious authority, in the sense that the logic that takes over traditional authority is not intentionally carried out, but is accidentally taken ${ }^{15}$. However, the solution given by Pauline Hope Cheong in her view to overcome the above is the logic of Complementarity, namely the logic of collaborative thinking about the internet that helps formulate the development of traditional authority ${ }^{16}$.

Through the description of the theory above, this article will use the theory of religious authority on a phenomenon of displacement of religious authorities using online videos by vlog videos about religious messages that are not from religious authorities. In this article, we will explain how vlogs have taken over the world of religious

12 Haula Noor, "Dinamika Otoritas Keagamaan Di Indonesia," Jurnal Indo-Islamika 2, no. 2 (2012): 31116, https://doi.org/10.15408/idi.v2i2.1188.

${ }^{13}$ Campbell, Digital Religion: Understanding Religious Practice in New Media Worlds.

14 Muhammad Rofiq, "Krisis Ototirtas Keagamaan Kontemporer: Literalisme Berjubah Salafi," Jurnal TARJIH 11, no. 1 (2013): 99-112; Fazlul Rahman, "Otoritas Keagamaan Nyai Pandalungan: Dinamika Otoritas Keagamaan Perempuan Dalam Konteks Budaya Lokal," Annual Conference for Muslim Scholars (AnCoMS) Kopertais Wilayah IV Surabaya 17, no. 1 (2018): 959-71.

${ }^{15}$ Campbell, Digital Religion: Understanding Religious Practice in New Media Worlds.

${ }^{16}$ Campbell. lectures by using Nas Daliy's video object that talks about religion.

As previously mentioned, this research has limitations, namely only in the virtual world. In this study, online media were used as objects to prove facts about vloggers taking over the function of religious authorities in disseminating religious content. Some of these media are, Facebook, Youtube, and Instagram. Nas Daily Has 20,302,902 followers on facebook, 4.67M Subscribers on Youtube, 2.9M followers on Instagram. However, here observers will be more focused on paying attention to the content on YouTube. One of the characters that observers use as an object is Steve Harvey, who once created content with Nas Daily.

\section{Nas Daily}

Nas Daily or Nusair Yassin is an Israeli palestinian vlogger. He was born in the city of Arraba to a Palestinian Muslim family. ${ }^{17}$ Nas Daily started his career as a video blogger by making 1000 one minute videos every day. ${ }^{18}$ This made Nas Daily famous just by making its 1000 video mission run.

On the 230th day Nas almost stopped making videos, but by the 400th day, 1 million people found Nas Daily's content, which was perched in the media and made it re-create content according to its mission. One of his million followers is a woman named Alyne who is now his life partner.

On the 609th day, Nas Daily's content exploded in cyberspace, making it appear in the mass media. On the 1000th day of Nas Daily he completed his mission and gained 11.8 million followers. On the 1001st day, Nas Daily opened Nas Studio to expand the production of video stories of people to social media. He re-opened his office in Singapore to

17 https://www.timesofisrael.com/for-israeliarab-one-minute-video-blogger-time-is-of-the-essence/ 18 https://www.nasdaily.com/\#history 
take part in the youth event of advanced Asia. ${ }^{19}$

Nas Daily published a book on "Around the world in 60 seconds" which summarizes everything he has learned from around the world. Nas Daily teamed up with spotify to create a podcast with the theme of Nas Talk on day 1350.

Nas academy is a kind of school for creators and prospective creators in creating content $^{20}$ which is not just a quiz but also contains an educational element. On the 1689th day Nas opened an office again in Dubai. And on the 1870th day, Nas received a donation of 11 million dollars for the development of future creators. And now ${ }^{21}$

${ }^{19} \mathrm{Ibid}$

20 The author is not a content creator, but I have registered at the Nas Academy and passed the test, this shows that NAS does not only open the Academy for content creators but also potential content creators.https:// nasacademy.com/nuseir?gclid=CjOKC QjwkbuKBhDRARIsAALysV75nV7qsjiJpBvqdviW414 ESwBgXFhpHB2ZLCSOSa2OP0pe7JpEq1IaAhddEA Lw wcB

${ }^{21}$ Not long ago, his plan to come to Indonesia was rejected by the government. It's not clear what caused it, but it may have been his Israeli passport. As is known, Indonesia and Israel do not have diplomatic relations. Yassin also announced this on August 31, 2017 on Facebook Nas Daily. Hello Indonesia: Only you can see this link. It is with great regret that I inform you that your country has refused me entry. I came from Singapore to apply for a visa to Indonesia because Indonesia is the only country I want to visit the most. For a Palestinian-Israeli like me, not everything is easy. You have to go through a complicated process and complete an authorization sheet. I followed the whole process step by step. Exactly as ordered. Only to find out later that my application was rejected. I don't know why, but it seems to have something to do with having my Israeli passport even though I'm a Muslim myself. I'm still not allowed in. Hopefully this status can be a notification for those who are kind enough to ask. I can't wait to visit Indonesia. I want to show the world the beauty of Indonesia in the purest and most political way. Unfortunately, it can't appear on Nas Daily. At least not in its current state. This is not goodbye. Goodbye. I'm sure one day we will meet. The country received 17 thousand likes, 2.9 thousand comments and was shared up to 6.3 thousand times. Many Indonesian internet users also support it. Not a few also linked President Joko Widodo's account in his comments, so Yassin recalled, "I saw many people linking the President's account. Haha you are so nice. I don't want
Nas Daily has 90 Members, and reaches 3.2\% of the world's population with 11 billion videos $^{22} 42$ million Followers and 100\% natural viewers. ${ }^{23}$

With his work as a travel vlogger, Yassin's video (real name from Nas Daily) has the opportunity to become a source of controversy. One example is when he just arrived in Singapore and made a series of videos about the positive side of the country. In the video entitled "Why I Hate Singapore", for example, Yassin shows how "jealous" he is to see the harmonious life in Singapore, the delicious culinary variety, and the world-class quality of Changi Airport. He also made the video 'Crazy Poor Asians', which shows the quality of life of the simple Singaporeans. The video subtly satirizes content in the style of "Crazy Rich Asians", the stereotype of Asian conglomerate kids with a jet-set lifestyle, which is often featured on social media.

Another controversial video is entitled "How Singapore cleans." The video shows the level of cleanliness in Singapore that far surpasses other countries. But because of the video, many internet users, especially from Singapore, accused Yassin of receiving payments from the government to promote positive things about his country. Yassin also denied the accusation. As reported by the Straits Times, Yassin had stated in the video comments column that all the videos he made about Singapore came from his personal pocket. "My videos in Singapore are not 100 percent funded by anyone. I came here and used my own money to make videos about their country. And I had to make sure of that." Late last month, Yassin was also denied entry

to do this politically because it just isn't. I'm sad I can't make videos in your country and I don't want to hide everything. Read more in the article "Knowing Who Nuseir "Nas Daily" Yassin is ", https://tirto.id/cWE6

\section{2 https://www.nasdaily.com/\#history}

23 Natural audience is an audience that is not made up, all viewers automatically follow Nas Daily, including the writer himself. 
to Malaysia for the same reasons he experienced in Indonesia: from Israel. However, Yassin's reaction to Malaysia was a bit harsher than when he was rejected in Indonesia. He even had time to make a video that Malaysia is the "Forbidden Land". "This country that you see behind me is very difficult to enter, like North Korea. With my Israeli passport, it is almost impossible for me to enter this country, and more for political reasons. Malaysia and Israel are not friends," Yassin said in the video. Among the various content Yassin created, his videos about relations between Israel and Palestine (and, of course, Jewish Muslims) were the ones that generated the sharpest reviews, such as several videos entitled Israel and Israel. Palestine (The Positive Version) and A Moslem and a Jude, which aired last year. The first video is a little longer than usual. At 7:25 minutes. The narration of the two videos is similar: a call for peace between the two sides. That conflict So far "only" politics and it's time to end it. In general, Yassin only conveyed a positive message, but precisely because of that, what had happened so far was underestimated. This was stated by Sarah Tawashy, a humanitarian activist, in a statement entitled "Nas daily misinterprets the conflict between Israel and Palestine", which aired on April 19, 2018 on The Cougar, the University student community website of Houston. . Tawashy sees Yassin's video as "propaganda" to "normalize" the conflict between Israel and Palestine and "deliberately does not understand the facts that have emerged so far." "Many of Yassin's videos are false narratives about the Israeli-Palestinian conflict. It is often mentioned in his videos that the background of the conflict between the two sides revolves around religion and the desire to own the city of Jerusalem. For Yassin, all of these problems can be solved if both sides resolve the existing differences because the main problem is only politics," Tawashy wrote. Tawashy also noted that Yassin never mentioned that there are so many Israelis who are "evil Zionists and" want a white Jewish state to be found. The fact that he is of Palestinian descent automatically makes him 'Arab' and allows him to spread propaganda while normalizing the Israeli occupation. In the video, he provides hilarious background music, which is considered very counterproductive. Especially if you ignore Israel's illegal settlements and the inhumane treatment of Palestinians by the Zionist army." I am not against peace and compassion. But when it is used to weaken the struggle of the oppressed, it becomes a problem. Colonizer and colonized, there is no talk between 'both sides'". Yassin never reacted to Tawashy's harsh criticism ${ }^{24}$.

\section{Facebook}

As Castells said in his book, one of the factors that influence the development of a network society is building a social structure with information through the technological paradigm ${ }^{25}$.

The main factor that makes researchers do the main observation on Facebook is because Nas Daily uses Facebook as the main platform used to disseminate its content. Facebook Nas Daily has 20,302,902 followers, followers from all over the world and from all religions and various kinds of Islamic orga itself ranging from religious and nonreligious. ${ }^{26}$ He has 10 accounts each of which has natural followers. The account is an account according to the language that the listener wants, including Spanish, Turkish, Indonesian, Arabic, Chinese, Thai, Ilati,

${ }^{24}$ More in the article "Kenali Siapa Nuseir" Nas Harian "Yassin", https://tirto.id/cWE6

${ }^{25}$ Manuel Castells, "The Network Society," The Network Society, 2013, https://doi.org/10.4337/9781845421663.

26 It can be proven from Nas Daily's Facebook account https://www.facebook.com/nasdaily 
Japanese, Tagalog, and English as the main account. $^{27}$

There are more than 1000 videos that have been uploaded by Nas daily to date, but they never exceed 5 to 6 minutes which makes the listeners not lazy to look on purpose and stop by to see ${ }^{28}{ }^{29}$ And Nas daily doesn't upload live videos which also makes people wait.

Nas Daily is a flexible Muslim, he uploads videos from various lines, there is no religious law in it, he uploads videos not in Muslim clothes but the people who upload are people with various clothes. Likewise, the people around him are also dressed and religious freely. ${ }^{30}$ This is a factor that causes more followers on Facebook and when viewed through semiotic observations, it becomes a sign of freedom of public consumption.

\section{Video Nas Daily and Religious Authorities}

Nas Daily is a peacemaker. He is a socialist who wants to convey that the whole world must unite despite different religions. This of course caused a lot of controversy and the strongest rebuke from religious authorities. Because religious authorities always say that their religion is the most correct while what their spare time by just scrolling up, a Nas Daily video appears which then we don't hesitate to stop by to stop for a moment to watch the video until it runs out because we know that the video is it won't take long. Even at certain times stop by the Nas Daily account to see other videos. This is one of the factors that can increase followers.

30 This does not need to be explained when it is known that he is not a religious authority but this is very unique to an Arab and a factor in increasing his Facebook followers.
}

Nas Daily teaches is back with that proposition.

There are several videos that talk about religion about peace. Orders for peace between religions, but this article will only sample three videos that will be the object of this comparison of authorities. Namely a video entitled (1) How This Country Fix The Religion, (2) How Steve Harvey Prays, (3) Am I A Bad Muslim.

The first video begins with his comments about religious authorities making beliefs with the proposition that reads "My Religion Is Better Then Your Religion" ${ }^{31}$. He explained that it was not the thought of one person, but the thought of everyone and that is what has made the chaos on earth until now still unfinished ${ }^{32}$. Then give an example of a country that eliminates that belief, that country is Emerat. In this country every religion has its own magnificent place of worship. There are 45 churches, many mosques, the magnificent Gurdwara (for Sikhs), Temple (for Mormons), and a synagogue (for Jews). The proposition that strengthens the problem of this research from this video is "This Is a big deal so many types of religions are living next to each other in peace" and "Im prettey sure you didn't expect that in Arabia"33. In the supermarket, there are two shopping blocks for Muslim and non-Muslim shops. There is also a bar which serves beer or other liquor freely without any hindrance. And what's interesting is that it all had to stop when the call to prayer sounded to respect Muslims. And non-Muslim activities stop instantly. And one of the things that strengthens the magnitude of tolerance in

${ }^{31}$ https://www.facebook.com/watch/?v $=28421$ $\underline{4366288391}$

${ }^{32}$ Junaidi Abdillah, "RADIKALISME AGAMA: Dekonstruksi Tafsir Ayat-Ayat 'Kekerasan' Dalam AlQur'an,” Kalam 8, no. 2 (2017): 281, https://doi.org/10.24042/klm.v8i2.224; Umi Hanik, "Pluralisme Agama Di Indonesia," Jurnal Pemikiran Keislaman 25, no. 1 (2014): 44-63, https://doi.org/10.33367/tribakti.v25i1.154.

33 Ibid 
Emerat is the existence of a mosque called "Mary The Mother of Jesus Mosque". In the case of a fatwa, there is an accident (not giving a fatwa) to Nas Dayli in conveying his religious ideas. He did not give a fatwa but conveyed how religion should be.

The next video tells about a successful comedian, tv host, entertainer from America who is also very religious named Steve Harvey. As in the video above, Nas Daily again tells about a religion that is not only one but this time in sentences.

"Often time people who are religious think their religion is right and everybody else is wrong there only one way to god." 34

$$
\text { Nas Daily }
$$

However, here Nas Daily takes facts from the uniqueness of religion that is believed by Steve Harvey. The successful comedian is unique in believing that there is no such thing as one in achievement.

"There is no one, one way to heaven, no one way to paradise, its like television, now there's over 800 channels of cable and they're all pretty entertaining, so im pretty sure man that to get to beaven there's gotte be more than the route becouse somebody watching another channel or taking another channel than you, they're still setting entertained and they probably still getting to heaven" 35

\section{Steve Harvey}

And according to Nas Daily this is not just a conversation but Steve Harvey is practicing it in his life as he gives names to his three children. Two of his children were given Christian names such as one named Brodrick and one was given a Muslim name, namely Ali as a sign of respect for the Islamic religion, and respect for Muslim culture. "Islam Is a religionofpiece, why you got a problem with peace?" said steve harvey as respect and understanding of the Islamic faith (Facebook, Nas Daily, 2020).

${ }^{34}$ https://www.facebook.com/watch/?v $=25818$ 1472329549

$$
35 \text { Ibid }
$$

The third video is about him as a Muslim. This video is his video about the answer to the comments of Muslims about him saying that he is a bad Muslim. Nas Named this video Am I A Bad Muslim.

"Over the past few months $i$ got a lot of criticism for being a bad Muslim, when $i$ showed you the gay capital of the world Castro in San Francisco $i$ was called a bad Mulism, when $i$ showed you alcohol in my video $i$ was called a bad Mulism, when $i$ showed you how prostitution is legal in senegal $i$ was called a bad Mulism, when $i$ drink, when $i$ dated, when $i$ traveled $i$ was told not to"

$$
\text { Nas Daily }
$$

He told that he was not a religious person but did not forget his identity as a Muslim. I don't force people to believe in my beliefs I don't ask for freedom ${ }^{36}$. A good religion is one who keeps his religion for himself, not to show it to others. And leave the world as it is ${ }^{37}$.

"We are not bad or good, we are just trying to live and let live"

$$
\text { Nas Daily }
$$

In fact, there are still many Nass Daily videos that talk about religion, which can be material for taking over the functions of religious authorities. However, in this study, as an observer, I just took 3 videos as samples. The three videos above are samples of the object of this discussion.

\section{Nas Daily's Displacement Video Against Religious Authorities.}

In general, the sole authority in religion is God ${ }^{38}$. The transfer of authority that occurs in the world, whether intentionally or unintentionally, will not change that single

36 Aflahal Misbah, "Fun and Religious Authority : Socializing Anti-Music on Instagram," Jurnal Masyarakat \& Budaya 21, no. 2 (2019): 149-68.

37 Aflahal Misbah, "Fashion Dalam Konstruksi Otoritas Ulama: Pandangan Kiai Shalih Darat," Jurnal Kajian Islam Interdisipliner 3, no. 1 (2018): 61-84.

38 Mutohharun Jinan, "New Media Dan Pergeseran Otoritas Keagamaan Islam Di Indonesia," Jurnal Lektur Keagamaan 10, no. 1 (2012): 181-208; Rumadi Rumadi, "Islam Dan Otoritas Keagamaan," Walisongo: Jurnal Penelitian Sosial Keagamaan 20, no. 1 (2012): 25, https://doi.org/10.21580/ws.20.1.183. 
authority. Most people who want to learn religion take it from books, but not everyone likes to read so the transfer of authority here also helps the person not to read but to see something visually finished, namely a video explaining religion. Here, religious videos also develop into videos that unintentionally talk about religion, which makes people less lazy to look for religious points because sometimes religious authorities convey religion with long explanations from the video that make some people bored. Of course, in today's era without forgetting the involvement of the internet as a media approach material ${ }^{39}$.

Pauline Hope Cheong said that religious authorities experience disjuncture, which means when a digital phenomenon issues a proposition that is not related to religion but accidentally the proposition is connected to religion at the basic point of religious teaching then religious students follow that authority which is not a religious authority as a basis for understanding religion ${ }^{40}$. The above theory is commonly used to examine the shift between traditional religious authorities to digital religious authorities ${ }^{41}$. Based on this, we can modify the above theory on the object of this study to become a deeper study after the digital study of religion. In this article the author puts religious authority in place of traditional authority on theory and makes video vlogs in place of digital religious authority on theory. In the first video, Nas

39 Ahmad Najib Burhani, "Aksi Bela Islam: Konservatisme Dan Fragmentasi Otoritas Keagamaan," Jurnal Maarif Institute 11, no. 2 (2016): 15-29; Mutohharun Jinan, "Intervensi New Media Dan Impersonalisasi Otoritas Keagamaan Di Indonesia," Jurnal Komunikasi Islam 03 (2013): 321-48; Didid Haryadi, "Otoritas Keagamaan Baru: Habituasi Dan Arena Dakwah Era Digital," Islamic Insights Journal 2, no. 2 (2020): 69-82,

https://doi.org/10.21776/ub.iij.2020.002.02.01.

${ }^{40}$ Campbell, Digital Religion: Understanding Religious Practice in New Media Worlds; Noor, "Dinamika Otoritas Keagamaan Di Indonesia."

${ }^{41}$ Campbell, Digital Religion: Understanding Religious Practice in New Media Worlds.
Daily makes the listener's position as a religious student who originally (the listener) did not aim to seek religious knowledge, but saw the development of exploration carried out by Nas Daily, but accidentally understood a religious phenomenon that was used as a motivation and religious lesson. In the second Nas Daily's video, there is an emphasis on the proposition that arises in the first video, the selection of this video is done because it is proof that the second video was uploaded in 2021 and the first video in 2020. This emphasizes the teachings of tolerance for nonreligious people. The third video that talks about him being commented on as a bad Muslim makes his followers follow his motivation which is made from responding to people's comments about his Islam. This answer makes religious people who are followers of Nas Daily believe that Nas is a video that can be seen also in seeking religious knowledge without having to search a lot for videos from religious authorities themselves.

Pauline Hope Cheong also wrote in her theory of authority through the second logic, the logic of displacement. This is a continuation of the logic of disjuncture which means that new authorities who begin to enter the world of traditional authority occupy the place of traditional authority and transfer traditional authority to another place. ${ }^{42}$. In this theory, it is explained that digital authorities occupy traditional religious authorities who initially accidentally entered the world of religious authorities ${ }^{43}$. So the researchers modified it as a disjuncture, so it can be concluded that the Nas Daily Vlog video is a video that becomes a reference in seeking motivation for religious knowledge without having to listen to it directly from religious authorities. Like the first and second videos of Nas Daily, which are the legitimacy of religious law, it is not permissible to believe

\footnotetext{
${ }^{42}$ Campbell.

${ }^{43}$ Campbell.
} 
that my religion is the truest. And in the third video it is made that we can live freely and be good people without having to pay attention to religious authorities who say whether your Islam is good or your Islam is bad. So the proposition made through the authority of the Nas Daily vlog becomes a takeover for many people because the listeners of Nas Daily are not only people from one religion but people from other religions around the world as well. And it doesn't just stop at that stage, in contrast to religious authority which is only desired by people who seek religious knowledge. Nas Daily is also followed by religious people who don't really want to study religious sciences. And of course the number of these people outnumbered certain listeners of religious authorities. So that Nas daily became a displacement of religious authority.

\section{Alternative Perspectives for Religious Authorities}

Pauline Hope Cheong raised two logics as an alternative to the problematic facts of the analysis of religious authorities through the logic of disjucture and displacement. That is the logic of authority through the logic of continuity and complementarity.

Pauline Hope Cheong said in the logic of continuity that digital media authorities enter the realm of religion on the basis of religion, meaning that digital media authorities do not interfere with traditional religious authorities and when digital media begins to enter the realm of religion, religious authorities want this because basically there is no conflicting belief. back with traditional religious authorities so that religious authorities become more successful in their development through digital media ${ }^{44}$. The object in this article will modify the continuity theory as above. From here, the researcher took personal data from Nas Daily. $\mathrm{He}$ himself is a Muslim who practices religion as religious authorities explain how this religion is practiced. And the first and second videos do not show any takeover from the place of religious authority to its own. However, it contains a message that aims for the common development of religious communities where the message will not interfere with religious authorities. The third video does not tell about the faults of religion itself but the depiction of religion through stories about itself.

Pauline Hope Cheong Explains that the complementarity of action shows how the media advances religious authority in its development ${ }^{45}$. We can see this complementarity from the first and second videos that religion is not a problem, but religion that makes religion a religious problem. This is evidenced by the video that depicts Steve Harvey's faith which explains that religion is a solution to success.

From here, Nas Daily can be said to be a user and mentor of New Media. The author says mentor because this will be involved in the process of rejuvenating Ulama.

\section{Conclusion}

The Nas Daily Vlog video is a solution for non-religious people who are less willing to seek religious knowledge from the religious authorities themselves. Which started without a religious invitation but gave rise to the idea of good religious treatment. This makes the vlog complete from religious teachings brought by the religious authorities themselves. Because most religious authorities will give birth to religious authorities again, which still can't beat video vlogs with explanations about more complex social life, which also mentions religious phenomena. Which is the answer about how this religion should be

\footnotetext{
${ }^{45}$ Campbell.
} 


\section{References}

Abdillah, Junaidi. "Radikalisme Agama: Dekonstruksi Tafsir Ayat-Ayat 'Kekerasan' Dalam Al-Qur'an.” Kalam 8, no. 2 (2017): 281. https://doi.org/10.24042/klm.v8i2.224.

Akmaliah, Wahyudi. "Bukan Sekedar Penggaung (Buzzers): Media Sosial Dan Transformasi Arena Politik." Maarif 13, no. 1 (2018): $9-25$. https://doi.org/10.47651/mrf.v13i1.9.

Arrobi, Mohammad Zaki, and Amsa Nadzifah. "Otoritas Agama Di Era Korona: Dari Fragmentasi Ke Konvergensi?" Maarif 15, no. 1 (2020): 197-215.

https://doi.org/10.47651/mrf.v15i1.85.

Biel, Joan-isaac, Oya Aran, and Daniel GaticaPerez. 'You Are Known by How You Vlog: Personality Impressions and Nonverbal Behavior in YouTube." Artificial Intelligence, 2011, 446-49.

Biel, Joan Isaac, and Daniel Gatica-Perez. "Voices of Vlogging." ICWSM 2010 Proceedings of the 4th International $A A A I$ Conference on Weblogs and Social Media, 2010, 211-14.

Burhani, Ahmad Najib. "Aksi Bela Islam: Konservatisme Dan Fragmentasi Otoritas Keagamaan." Jurnal Maarif Institute 11, no. 2 (2016): 15-29.

Campbell, Heidi A. Digital Religion: Understanding Religious Practice in New Media Worlds. Digital Religion: Understanding Religious Practice in New Media Worlds, 2012.

https://doi.org/10.4324/9780203084861

Castells, Manuel. "The Network Society." The Network Society, 2013. https://doi.org/10.4337/9781845421663

Fahyuni, Eni Fariyatul, and Wilna Aini. "Pengembangan Video Pembelajaran Tutorial Sujud Pada Mata Pelajaran Pendidikan Agama Islam Pada Sekolah Menengah Pertama." Halaqa: Islamic
Education Journal 3, no. 1 (2019): 43-52. https://doi.org/10.21070/halaqa.v3i1.21 16.

Gao, Wen, Yonghong Tian, Tiejun Huang, and Qiang Yang. "Vlogging: A Survey of Videoblogging Technology on the Web." ACM Computing Surveys 42, no. 4 (2010). https://doi.org/10.1145/1749603.17496 06.

Griffiths, Mark D. "Facebook Addiction." Psychiatria Hungarica: A Magyar Psqichiatriai Tarsasag Tudomanyos Folyoirata 33, no. 1 (2018): 25-34.

Hanik, Umi. "Pluralisme Agama Di Indonesia." Jurnal Pemikiran Keislaman 25, no. 1 (2014): 44-63. https://doi.org/10.33367/tribakti.v25i1. 154.

Haryadi, Didid. "Otoritas Keagamaan Baru: Habituasi Dan Arena Dakwah Era Digital." Islamic Insights Journal 2, no. 2 (2020): 69-82. https://doi.org/10.21776/ub.iij.2020.002 .02 .01 .

Haryanto, Dwi. "Komodifikasi Agama Pada Media Sinema Sebagai Strategi Jualan Industri Perfilman Indonesia." Journal of Urban Society's Arts 4, no. 2 (2018): 61-70. https://doi.org/10.24821/jousa.v4i2.216 1.

Huang, Ting Hao, Francis Ferraro, Nasrin Mostafazadeh, Ishan Misra, Aishwarya Agrawal, Jacob Devlin, Ross Girshick, et al. "Visual Storytelling." 2016 Conference of the North American Chapter of the Association for Computational Linguistics: Human Language Technologies, NAACL HLT 2016 - Proceedings of the Conference, no. Dii (2016): 1233-39. https://doi.org/10.18653/v1/n16-1147.

Jinan, Mutohharun. "Intervensi New Media Dan Impersonalisasi Otoritas Keagamaan Di Indonesia." Jurnal Komunikasi Islam 03 (2013): 321-48.

. "New Media Dan Pergeseran Otoritas Keagamaan Islam Di Indonesia." Jurnal Lektur Keagamaan 10, no. 1 (2012): 181-208. 
Misbah, Aflahal. "Fashion Dalam Konstruksi Otoritas Ulama: Pandangan Kiai Shalih Darat." Jurnal Kajian Islam Interdisipliner 3, no. 1 (2018): 61-84.

- "Fun and Religious Authority: Socializing Anti-Music on Instagram." Jurnal Masyarakat \& Budaya 21, no. 2 (2019): 149-68.

Mustaqim, Mujahidil. "Analisis Nilai-Nilai Toleransi Dalam Kurikulum Pendidikan Agama." Jurnal Pendidikan Agama Islam 16, no. 1 (2019): 75-94. https://doi.org/10.14421/jpai.2019.16105.

Noor, Haula. "Dinamika Otoritas Keagamaan Di Indonesia." Jurnal Indo-Islamika 2, no. 2 (2012): 311-16. https://doi.org/10.15408/idi.v2i2.1188.

Nurjanah, Citra, Jujun Junaedi, and Uwes Fatoni. "Pesan Dakwah Minoritas Dalam Vlog." Tabligh: Jurnal Komunikasi Dan Penyiaran Islam 5, no. 4 (2020): 425-42. https://doi.org/10.15575/tabligh.v5i4.14 85.

Rahman, Fazlul. "Otoritas Keagamaan Nyai Pandalungan: Dinamika Otoritas Keagamaan Perempuan Dalam Konteks Budaya Lokal." Annual Conference for Muslim Scholars (AnCoMS) Kopertais Wilayah IV Surabaya 17, no. 1 (2018): 959-71.
Rizky, Fasha Umh, and Nur Syam. "Mengubah Sikap Moderasi Beragama Di Universitas Islam Negeri Sunan Ampel Surabaya." Jurnal Ilmu Komunikasi 11, no. 1 (2021).

Rofiq, Muhammad. "Krisis Ototirtas Keagamaan Kontemporer: Literalisme Berjubah Salafi." Jurnal TARJIH 11, no. 1 (2013): 99-112.

Roy, Oliver. The Failure of Political Islam. Cambridge: Harvard University Press, 2003.

Rumadi, Rumadi. "Islam Dan Otoritas Keagamaan." Walisongo: Jurnal Penelitian Sosial Keagamaan 20, no. 1 (2012): 25. https://doi.org/10.21580/ws.20.1.183.

Wahidin, Unang. "Implementasi Literasi Media Dalam Proses Pembelajaran Pendidikan Agama Islam Dan Budi Pekerti." Edukasi Islami : Jurnal Pendidikan Islam 7, no. 02 (2018): 229. https://doi.org/10.30868/ei.v7i2.284.

Waluyajati, Roro Sri Rejeki, and Herlina Nurani. "Islam Dan Studi Agama-Agama Di Indonesia." Religious: Jurnal Agama Dan Lintas Budaya 1, no. 1 (2016): 51-62.

\section{Digital \& Sosial Media}

https://www.timesofisrael.com/for-israeliarab-one-minute-video-blogger-time-isof-the-essence/

https://www.nasdaily.com/\#history 